\title{
PEMBELAJARAN OUTBOUND SAINS YANG BERMAKNA (MEANINGFUL LEARNING) DAN INOVATIF DI MADRASAH IBTIDAIYAH
}

\author{
Zulvia Trinova. \\ Jurusan Pendidikan Agama Islam Fakultas Tarbiyah IAIN Imam Bonjol Padang \\ Korespondensi: Jl. Rokan No. 12 Padang Barat \\ E-mail: zulviatrinova12@gmail.com
}

\begin{abstract}
Outbound Science provides active and enjoyable learning atmosphere that guarantees students not easily to get fed up and tired during the learning process. Such supporting atmosphere facilitates the students' comprehension on the concept of science. Outbound science learning is carried out in order that the students can experience directly the concept they are learning about, develop their logical reasoning and teach them to acquire spiritual, emotional and intellectual optimally. After all, innovative learning is intended to activate students in order to improve educational quality by promoting student-centered learning in which instructional materials are made to be related to students' daily life experience and meaningful as well.
\end{abstract}

Kata kunci: outbound sains, meaningful learning (pembelajaran bermakna), inovatif.

\section{PENDAHULUAN}

$\mathrm{B}$ erdasarkan Kurikulum Sains MI, sains merupakan cara mencari tahu tentang alam sekitar secara sistematis untuk menguasai pengetahuan, fakta-fakta, konsep-konsep, prinsipprinsip, proses penemuan, dan memiliki sikap ilmiah. Pembelajaran sains menekankan pada pengalaman langsung dan kegiatan praktis untuk mengembangkan kompetensi agar siswa memahami alam sekitar secara ilmiah. Selanjutnya, diarahkan untuk mencari tahu dan berbuat sehingga dapat membantu siswa untuk memperoleh pemahaman yang lebih mendalam tentang alam sekitar.

Pembelajaran sains digunakan sebagai wahana bagi siswa untuk menjadi ilmuwan, terutama siswa tingkat
Madrasah Ibtidaiyah (MI). Melalui pembelajaran sains di sekolah siswa dilatih berpikir, membuat konsep ataupun dalil melalui pengamatan, dan percobaan. Namun hal tersebut berbeda dengan realita di lapangan masih terkendala untuk mewujudkan idealita tersebut.

Perkembangan ilmu pengetahuan, teknologi dan seni (IPTEKS) yang pesat saat ini berakibat pada perubahan-perubahan di berbagai bidang kehidupan. Mulyasa (2008: 9) mengemukakan bahwa pendidikan harus dapat memenuhi tuntutan dan kebutuhan masyarakat, terutama dalam kaitannya dengan permasalahan-permasalahan perkembangan IPTEKS.

Beberapa fakta yang dapat diketahui, siswa kurang didorong untuk 
mengembangkan kemampuan berpikir. Proses pembelajaran di dalam kelas didominasi oleh kegiatan belajar yang sifatnya kognitif saja, yang sifatnya menghafal dan mengingat berbagai materi saja. Siswa tidak dituntut untuk memahami dan menghubungkan informasi dan menghubungkannya dengan kehidupan sehari-hari mereka. Dengan demikian, pembelajaran dengan menerapkan pendekatan tersebut kurang mendorong siswa untuk dapat mengembangkan kemampuan berpikir.

Dewasa ini, sepertinya pembelajaran yang dilakukan masih belum bermakna. Sebagaimana diungkapkan Abdurrahman (2007: 100) bahwa selama mengikuti pembelajaran di sekolah, siswa jarang bersentuhan dengan pendidikan nilai yang berorientasi pada pembentukan watak dan kepribadian. Hal tersebut mengakibatkan pembelajaran kurang bermakna dan juga mengakibatkan siswa kurang termotivasi untuk mempelajari sains yang ditunjukkan dengan sikap bosan mengikuti proses pembelajaran sehingga sains kurang berkesan dalam benak mereka (Martin, et. al., 2005: 6). Dengan demikian, perlu suatu pendekatan pembelajaran yang sesuai dengan tahap perkembangan intelektual siswa dan dapat memberikan makna bagi siswa untuk dapat menjadi manusia seutuhnya.

Pembelajaran outbound sains memungkinkan siswa mengalami langsung konsep yang dipelajari serta mengembangkan penalaran logis dan meng-ajarkan siswa untuk menguasai nilai-nilai spiritual, emosional dan intelektual secara optimal. Hal itu dikarenakan materi pembelajaran dapat dirangkum menjadi kegiatan yang dekat dengan pengalaman siswa dalam kesehariannya sehingga menjadi bermakna bagi kehidupan.

\section{OUTBOUND SAINS}

Bumi ciptaan Allah, SWT merupakan alam yang kaya akan pengetahuan. Alam tersebut tidak akan dapat dipelajari siswa di dalam ruangan, namun dapat diperoleh siswa di luar ruangan, sehingga siswa dapat belajar dan membuktikan apa yang diterimanya di kelas. Ada beberapa tahapan yang dapat dilakukan siswa untuk memudahkan masuknya informasi, yaitu mendengar, menulis atau menggambar lalu melihat dan melakukan percobaan sendiri. Misalnya, belajar tentang ikan, siswa dapat mengeksplorasi ikan, misal jenis-jenis ikan, bagian-bagian organ ikan, kegunaan ikan, dan sebagainya. Guru hendaknya dapat mengajak siswa untuk melakukan observasi di lapangan, misalnya mengamati, menyentuh atau meraba dan menganalisis obyek yang dimaksud. Contohnya, siswa melakukan observasi untuk mengenal bagian dari hewan, misalnya mulut, kaki, tanduk, ekor, dan sebagainya. Selain itu, guru juga memaparkan pada siswa masingmasing fungsinya dan bentuknya yang beragam sehingga siswa belajar mengenal apa yang ada di alam melalui semua inderanya.

Pembelajaran sains dengan memanfaatkan lingkungan dapat dilakukan dengan cara membawa lingkungan ke dalam kelas, seperti: menghadirkan pemateri untuk menyampaikan materi di dalam kelas. Selanjutnya, agar penggunaan lingkungan sebagai sumber belajar berjalan efektif, maka perlu dilakukan perencanaan, pelaksanaan dan evaluasi, serta tindak lanjutnya. Di samping itu pemanfaatan lingkungan dapat ditempuh dengan cara melakukan kegiatan dengan membawa siswa ke lingkungan, seperti survey, karyawisata, berkemah, praktek lapangan, dan sebagainya.

Outbound adalah suatu program pembelajaran di alam terbuka yang berdasarkan pada prinsip experiential learning (belajar melalui pengalaman 
langsung) yang disajikan dalam bentuk permainan, simulasi, diskusi dan petualangan sebagai media penyampaian materi. Artinya dalam program outbound tersebut siswa secara aktif dilibatkan dalam seluruh kegiatan yang dilakukan. Kegiatan belajar yang langsung terlibat pada aktivitas (learning by doing) siswa akan segera mendapat umpan balik tentang dampak dari kegiatan yang dilakukan, sehingga dapat dimanfaatkan sebagai bahan pengembangan diri setiap siswa dimasa mendatang. Hal tersebut juga dapat diartikan bahwa proses belajar dari pengalaman (experiental learning) dengan menggunakan seluruh panca indera (global learning) yang nampaknya rumit, memiliki kekuatan karena situasinya "memaksa" siswa memberikan respon spontan yang melibatkan fisik, emosi, dan kecerdasan sehingga secara langsung mereka dapat lebih memahami diri sendiri dan orang lain serta lingkungannya.

Selain itu, outbound juga dikenal dengan sebutan media outbound activities. Outbound merupakan salah satu metode pembelajaran yang dapat digunakan oleh guru di MI melalui interaksi antar siswa dan alam melalui kegiatan simulasi di alam terbuka. Hal tersebut diyakini dapat memberikan suasana yang kondusif untuk membentuk sikap, cara berfikir serta persepsi yang kreatif dan positif dari setiap siswa. Selain itu, melalui simulasi outdoor activities, siswa juga akan mampu mengembangkan potensi diri, baik secara individu (personal development) maupun dalam kelompok (team development). Tujuan outbound menurut Adrianus dan Yufiarti adalah untuk:

1. Mengidentifikasi kekuatan dan kelemahan diri siswa.

2. Berekspresi sesuai dengan caranya sendiri yang masih dapat diterima lingkungan.
3. Mengetahui dan memahami perasaan, pendapat orang lain dan memahami perbedaan.

4. Membangkitkan semangat dan motivasi untuk terus terlibat dalam kegiatan-kegiatan.

5. Lebih mandiri dan bertindak sesuai dengan keinginan.

6. Lebih empati dan sensitif dengan perasaan orang lain.

7. Mampu berkomunikasi dengan baik.

8. Mengetahui cara belajar yang efektif dan kreatif.

9. Memberikan pemahaman terhadap sesuatu tentang pentingnya karakter yang baik.

10. Menanamkan nilai-nilai yang positif sehingga terbentuk karakter siswa melalui berbagai contoh nyata dalam pengalaman hidup.

11. Membangun kualitas hidup siswa yang berkarakter.

12. Menerapkan dan memberi contoh karakter yang baik kepada lingkungan (http://widhoy.multiply.com)

Kegiatan outbound sains merupakan kegiatan belajar sambil bermain atau sebaliknya. Menurut Vygotsky (Tedjasaputra, 2001: 10) bermain mempunyai peran langsung terhadap perkembangan kognisi seorang anak dan berperan penting dalam perkembangan sosial dan emosi anak. Menurut Heterington dan Parke (Moeslichatoen, 1999: 34), bermain juga berfungsi untuk mempermudah perkembangan kognitif anak. Belajar sambil bermain memungkinkan anak meneliti lingkungan, mempelajari segala sesuatu dan memecahkan masalah yang dihadapinya. Bermain juga meningkatkan perkembangan sosial anak serta untuk memahami peran orang lain dan menghayati peran yang akan diambilnya setelah ia dewasa.

Dworetzky (Moeslichatoen, 1999: 34) mengemukakan bahwa fungsi bermain dan interaksi dalam permainan mempunyai peran penting bagi per- 
kembangan kognitif dan sosial siswa. Jadi berdasarkan pendapat para ahli tersebut dapat disimpulkan bahwa manfaat bermain tidak saja dapat meningkatkan perkembangan kognitif dan sosial, tetapi juga perkembangan bahasa, disiplin, perkembangan moral, kreativitas, dan perkembangan fisik siswa.

Outbound sains akan menyajikan pembelajaran aktif dan menyenangkan sehingga siswa tidak cepat jenuh dan bosan dalam proses pembelajaran. Suasana kegiatan outbound sains yang menarik dan menyenangkan akan mempermudah siswa dalam pemahaman konsep sains, dan dapat meningkatkan perkembangan psikomotor dan afektif siswa, serta menjadikan pembelajaran akan lebih bermakna. Selain itu, terdapat keuntungan-keuntungan pembelajaran dengan menggunakan outbound sains berdasarkan uraian di atas antara lain yaitu.

1. Membuat proses pembelajaran berpusat pada siswa yang menjadikan proses belajar menyangkut semua aspek yang memungkinkan siswa berkembang sebagai individu yang dapat berfungsi secara menyeluruh.

2. Memungkinkan siswa membentuk self concept sehingga siswa dapat mengenal dirinya sendiri lebih baik, yaitu mengenal kelebihan dan kekurangan dirinya.

3. Melatih siswa untuk mengkonstruk konsep dari pengalaman-pengalamannya yang menyenangkan

4. Mengembangkan bakat-bakat siswa

5. Mencegah siswa belajar hanya pada tingkat verbal saja

6. Belajar secara bermain memberi waktu kepada siswa untuk mengasimilasi dan mengakomodasi informasi.

Pendekatan outbound cocok diterapkan karena adanya perbedaan-perbedaan individu dalam kelas. Pada pendekatan ini, siswa diberi rangsangan untuk menemukan konsep yang akan dipelajari dengan dibimbing oleh guru. Adapun kelemahan dari pembelajaran dengan outbound sains yaitu:

1. Waktu yang digunakan relatif lama.

2. Membutuhkan peralatan dan sumber belajar yang beragam.

3. Tenaga yang dibutuhkan lebih banyak.

4. Ide permainan dan memberi makna pada tiap konsep memerlukan kreativitas dan perhatian yang lebih dari guru.

Prosedur mempersiapkan pembelajaran dengan outbound sains siswa (experiental learning) menurut Oemar Hamalik (2003: 47) adalah sebagai berikut:

1. Guru merumuskan dengan teliti pengalaman belajar yang direncanakan untuk memperoleh hasil yang potensial atau memiliki alternatif hasil.

2. Guru berusaha menyajikan pengalaman yang bersifat menantang dan memotivasi.

3. Siswa dapat bekerja secara individual, tetapi lebih sering bekerja dalam kelompok-kelompok kecil.

4. Para siswa ditempatkan dalam situasi-situasi pemecahan masalah yang nyata.

5. Para siswa secara aktif berperan serta dalam pembentukan pengalaman membuat keputusan sendiri dan memikul konsekuensi atas keputusan-keputusan tersebut.

Menurut Gordon dan Browne (Moeslichatoen, 1999: 57-58) terdapat beberapa aspek yang perlu diperhatikan dalam memilih bahan dan peralatan outbound sains yaitu antara lain:

1. Memilih bahan untuk kegiatan bermain yang mengundang perhatian semua siswa, yakni bahanbahan yang dapat memuaskan 
kebutuhan, menarik minat, dan menyentuh perasaan mereka.

2. Memilih bahan yang multi guna yang dapat memenuhi bemacam tujuan pengembangan seluruh aspek perkembangan siswa.

3. Memilih bahan yang dapat memperluas kesempatan siswa untuk menggunakannya dengan bermacam cara.

4. Memilih bahan yang mencerminkan karakteristik tingkat usia kelompok siswa.

5. Memilih bahan harus sesuai dengan filsafat dan napas kurikulum yang dianut.

6. Memilih bahan yang mencerminkan kualitas rancangan dan keterampilan kerja.

7. Memilih bahan dan peralatan yang tahan lama.

8. Memilih bahan-bahan yang dapat dipergunakan secara fleksibel dan serba guna.

9. Memilih bahan yang mudah dirawat dan diperbaiki.

10. Memilih bahan yang mencerminkan peningkatan budaya kelompok.

11. Memilih bahan yang tidak membedakan jenis kelamin dan meniru-niru.

Pembelajaran dengan outbound ini yang berdasarkan pengalaman ini menyediakan suatu alternative pengalaman belajar bagi siswa yang lebih luas daripada pendekatan yang diarahkan oleh guru kelas di MI. Strategi ini menyediakan banyak kesempatan belajar secara aktif, personalisasi dan kegiatan-kegiatan belajar yang lainnya bagi para siswa untuk semua tingkat usia. Pembelajaran ini guru dapat menginternalisasikan dimensi spiritual ke dalam kegiatan belajar siswa, agar apa yang siswa pelajari dapat mendekatkan siswa kepada Allah SWT (Sang Pencipta).
Adapun hal-hal yang perlu dipersiapkan dalam kegiatan pembelajaran ini adalah:

1. Menentukan bentuk kegiatan yang akan dipakai Kegiatan outbound ini dapat divariasi sendiri oleh guru. Misalnya: dalam satu materi dapat dilakukan dengan berbagai bentuk, seperti dalam tema yang lain seperti lingkungan.

2. Menentukan waktu pelaksanaan kegiatan. Kegiatan outbound ini dapat dilaksanakan dalam pembelajaran atau dapat juga dilaksanakan di luar jam pelajaran.

3. Menentukan rute perjalanan Outbound ini dapat dilakukan satu kelas bersama-sama dengan sistem kompetisi dan dapat juga dilakukan dengan giliran kelompok/rooling, hal tersebutdisesuaikan dengan kemampuan dan jumlah guru. Outbound dapat menggunakan rute di sekitar sekolahan atau di lingkungan warga sekitar. Pembelajaran ini juga dapat dilakukan hanya dengan berpindah pos saja.

4. Mempersiapkan peralatan dan bahan yang dibutuhkan di tiap pos.

a) Jika menggunakan sistem kompetisi: semakin banyak kelompok yang dibentuk maka peralatannya semakin banyak.

b) Jika menggunakan sistem roling: peralatan yang dibutuhkan sedikit.

5. Menentukan dan mempersiapkan petugas pos. Jika dalam bentuk rolling maka diperlukan lebih banyak penjaga pos daripada dengan sistem kompetisi. Tiap penjaga pos dipersiapkan untuk dapat mengisi pos yang dipegangnya. Untuk menyamakan persepsi tema yang akan diajarkan maka perlu diadakan briefing. 
6. etelah semua persiapan selesai maka tahap selanjutnya pelaksanaan kegiatan outbound .

a) Guru membagi siswa menjadi beberapa kelompok.

b) Guru menjelaskan tentang benda dan sifatnya:

c) Guru menjelaskan aturan permainan outbound.

Setelah kegiatan outbound, guru bersama siswa MI membahas kembali apa yang telah dilaksanakan. Metode yang digunakan yaitu metode diskusi, dimana akan diperoleh pendapat yang berbeda dan bervariasi antara siswa yang satu dengan yang lainnya. Guru bertugas menfasilitasi dalam menyisipkan makna (misal pesan moral, sikap dan kerjasama). Misalnya, dalam kegiatan ini yaitu: Udara yang ada di dalam balon memberikan tekanan sehingga ketika dilepaskan balon dapat berlari menuju ke ujung benang yang lain. Udara merupakan benda gas yang mempunyai sifat bentuknya berubah-ubah sesuai dengan tempatnya, udara dapat memberikan tekanan, udara tidak terlihat dan tak dapat dipegang namun bisa dirasakan, dan udara ada di mana-mana/ada di sekitar. Semakin banyak udara dalam balon maka balon juga akan tampak besar dan tekanannya juga besar. Tekanan besar maka larinya semakin cepat artinya dalam kehidupan ini kita harus mengisi kehidupan (seperti balon) dengan menambah wawasan, akhlak yang baik, dan keterampilan-keterampilan, selain itu juga harus memupuk semangat, motivasi dan kemauan yang besar agar akan dapat berlari dengan cepat untuk mencapai cita-cita. Kemudian siswa diarahkan pada pemanfaatan apa yang sedang dipelajari dengan kehidupan mereka sehingga menjadi orang yang pandai bersyukur. Sebagai contoh: udara dapat dimanfaatkan untuk:

1. Mengisi ban kendaraan, tanyakan kepada siswa berapa banyak udara yang di masukkan ke dalam ban kendaraan (sedikit/banyak?) dan dapatkah udara dalam ban-ban tersebut mengangkat 50 orang? Dan berilah tanggapan pada siswa bahwa: meskipun udara yang kita berikan pada ban sedikit, akan tetapi udara memberikan tekanan pada ban sehingga ban menjadi keras dan dapat digunakan kendaraan seperti bus untuk mengangkut 50 orang atau lebih.(jangan menganggap hal yang sepele, karena hal yang sepele kadang adalah sesuatu yang besar pengaruhnya bagi kehidupan).

2. Bernafas, tanyakan dari manakah udara yang kita hirup? Bagaimanakah ketika hidungmu tersumbat? bayarkah kita untuk menghirup udara di sekitar kita? Hitunglah berapa banyak tabung gas yang kita perlukan untuk bernafas hingga hari ini? Siapakah yang menciptakan udara? Dan berikanlah tanggapan pada siswa bahwa: kita dapat bebas bernafas, menghirup udara sebebasbebasnya dimanapun kita berada, diberi nikmat kesehatan sehingga dapat bernafas dengan baik Gratis dan jika kita harus bernafas dengan tabung gas maka berapa uang yang akan dikeluarkan hingga kita hidup sampai hari ini. Ini adalah karunia Allah swt. Bersyukurlah atas segala nikmatNya.

3. Membantu pembakaran, dan lainlain.

\section{PEMBELAJARAN INOVATIF}

Santyasa (2005: 5) menyatakan bahwa pembelajaran inovatif adalah pembelajaran yang lebih bersifat student centered, artinya pembelajaran yang lebih memberikan peluang kepada siswa untuk mengkonstruksi pengetahuan secara mandiri (self directed) dan dimediasi oleh teman sebaya. Dapat disimpulkan bahwa pembelajaran inovatif 
adalah pembaharuan pendidikan yang mengaktifkan siswa untuk meningkatkan kualitas pendidikan dengan menciptakan pembelajaran student centered.

Menurut Marsaja (2007) keunggulan pembelajaran inovatif adalah: (a) kualitas hasil belajar yang dicapai menjadi lebih tinggi, (b) lingkup hasil belajar menjadi lebih komprehensif, (c) pembelajaran inovatif tidak saja menekankan pada hasil belajar kognitif, tetapi juga hasil belajar proses dan sikap. Konsekuensinya tentu akan memerlukan waktu yang lebih lama karena dilakukan untuk mencapai banyak hasil belajar. Pembelajaran inovatif dengan metode yang berpusat pada siswa (student centered learning) juga memiliki keragaman model pembelajaran yang menuntut partisipasi aktif dari siswa. Metode-metode tersebut di antaranya sebagai berikut:

1. Berbagi informasi (information sharing) dengan cara: curah gagasan (brainstorming), kooperatif, kolaboratif, diskusi kelompok (group discussion), diskusi panel (panel discussion), simposium, dan seminar

2. Pembelajaran melalui pemecahan masalah (problem solving based learning) dengan cara: studi kasus, tutorial, dan lokakarya.

3. Belajar dari pengalaman (experience based) dengan cara: simulasi, bermain peran (roleplay), permainan (game), dan kelompok temu;

Salah satu metode alternatif yang saat ini sedang digemari dan diyakini lebih berhasil dari kegiatan ceramah adalah pendidikan luar ruang (outbound education), yang sarat dengan permainan yang menantang, mengandung nilai-nilai pendidikan, dan mendekatkan siswa dengan alam.

\section{MEANINGFUL LEARNING}

Pendidikan Indonesia saat ini sering lebih menitikberatkan pada bagaimana mengembangkan kecerdasan kognitif sehingga terjebak pada rasional oriented dan melepaskan orientasi irrasional maupun metafisik, semacam spiritual, dan konsep diri yang dianggap sebagai penghambat. Keadaan yang demikian mengakibatkan pembunuhan karakter yang dimiliki siswa dari sebuah kesatuan dalam dimensi kediriannya. Menurut Abdurrahman (2007: 74) proses pembelajaran meliputi keseluruhan unsur baik kognitif, afektif dan psikomotorik. Apabila proses pembelajaran tidak berjalan secara simultan maka akan terjadi split personality (diri yang terpisah) pada setiap siswa.

Gejala split personality ini tampak dalam perjalanan dunia pendidikan sekarang, tak terkecuali pendidikan sains. Hal ini menjadi tantangan bagi para guru untuk mengupayakan bagaimana melakukan pembelajaran yang menitikberatkan pada proses penyempurnaan manusia atau memanusiakan manusia (to be human) dan mengartikan hidup.

Siswa tidak hanya mampu menangkap pesan lahiriah dari apa yang ia pelajari, namun lebih dari itu siswa juga mampu memproyeksikan pesan dari setiap teori yang ia pelajari. Pendidikan adalah proses interaksi antara siswa dengan dirinya sendiri (konsentris), siswa dan alam sekitar (horizontal) dan interaksi siswa dengan Allah SWT (vertikal), tetapi banyak metode pengajaran sekarang yang memisah-misahkan ketiga interaksi tersebut. Oleh karena itu, guru hendaknya menyadari pentingnya pembelajaran yang bermakna dengan menciptakan keseimbangan antara guru, siswa, dan lingkungan. Hal tersebut dapat diwujudkan dengan memahami dan meeapkan berbagai metode atau model mengajar semisal CTL, Cooperative Learning, Quantum learning, Quantum 
Teaching, Accelerated Learning, dan sebagainya.

Metode belajar inovatif yaitu outbound sains dapat menjadi salah satu sarana yang dapat dimanfaatkan untuk mengembangkan pertumbuhan fisik dan perkembangan mental siswa seutuhnya sehingga terwujud pembelajaran yang bermakna. Artinya, siswa mampu membangun fisik dan mentalnya dengan belajar sambil bermain karena melalui permainan outbound sains akan terbangun suasana yang lepas, bebas, menyenangkan dan atraktif serta memberi makna dalam belajar siswa.

\section{PENUTUP}

Outbound merupakan salah satu metode yang dapat mengembangkan kemampuan berpikir, keterampilan sosial, life skill, kemampuan spiritual dan sikap

\section{DAFTAR RUJUKAN}

Abdurrahman. 2007. Meaningful Learning Re-Invensi Kebermakna-an Pembelajaran. Yogyakarta: Pustaka Pelajar

Adrianus dan Yufiarti. (http://widhoy. multiply.com/journal/item.15/ definisi_dan manfaat outbond. Diakses pada tanggal 6 Januari 2009.

Martin, et.al. 2005. Teaching science for all children: inquiry methods for constructing understanding-3rd edition. Pearson education. Inc.

Moeslichatoen, R. 1999. Metode Pengajaran di Taman Kanak-kanak. Jakarta: Penerbit Rineka Cipta.

Mulyasa. 2008. Implementasi KTSP Kemandirian Guru dan Kepala Sekolah. Jakarta: Bumi Aksara siswa. Prinsip "experiential learning" (belajar melalui pengalaman langsung) pada kegiatan outdoor ini, siswa akan mampu mengembangkan potensi diri, baik secara individu (Personal Development) maupun dalam kelompok (Team Development). Melalui outbound, siswa secara aktif dilibatkan dalam seluruh kegiatan yang dilakukan.dan langsung berinteraksi dengan alam untuk mengenal Allah SWT (Sang Pencipta) dan mencintai lingkungan, tempat hidupnya. Banyak orang yang mengetahui bahwa teknik tersebut dapat mengembangkan potensi siswa dan memberikan lingkungan belajar yang kreatif dan menyenangkan, akan tetapi guru jarang memanfaatkan outbound dalam pembeajaran secara formal. Padahal jika outbound ini dilakukan maka akan diperoeh kemanfaatan yang luar biasa.

Oemar Hamalik. 2003. Pendekatan Baru Strategi Belajar Mengajar berdasarkan CBSA. Bandung: Penerbit Sinar Baru Algesindo Bandung.

Santyasa, I Wayan. 2005. Model Pembelajaran Inovatif dalam Implementasi KBK, Makalah Penataran Guru-Guru SMP, SMA, dan SMK se- Kabupaten Jembrana Juni-Juli 2005. Jembrana: FMIPA IKIP Negeri Singaraja.

Tedjasaputra, Mayke S. 2001. Bermain mainan dan permainan untuk pendidikan usia dini. Jakarta: Grasindo. 